\title{
HERBAL NANOSUSPENSION: IN VITRO CANCER STUDY AGAINST DIFFERENT CELL LINES
}

\author{
MITHRA MM, KRISHNAKUMAR K, SMITHA K NAIR*
}

Department of Pharmaceutics, St. James' College of Pharmaceutical Sciences, St. James' Hospital Trust Pharmaceutical Research Centre (DSIR Recognized), Chalakudy, Kerala, India. Email: stjamespharmacyproject@gmail.com

Received: 05 April 2020, Revised and Accepted: 16 May 2020

ABSTRACT

Herbal formulations marketed in India for many years providing its therapeutic benefits in health problems. Medicinal plants or their phytoconstituents are less toxic and free from side effects than synthetic drugs. However, formulation aspects of these phytoconstituents are limited due to its low solubility. Nanotechnology is a promising technique to increase the solubility of herbal drugs. This will lead to a subsequent reduction in drug dose. Nanoformulations such as nanosuspension increase the solubility of poorly soluble drugs and also have good targeting effects on different cells. The efficacy of herbal nanosuspensions evaluated using different cell lines. Here, hepatocellular carcinoma cell line (SMMC-7721), human prostate cancer cell line, human myelogenous leukemia cell line, human epithelial cell line, human breast cancer cell lines (4T1, MCF-7, and MDA-MB-453), carcinomic human alveolar basal epithelial cell line (A549), human umbilical vein endothelial cell line, human colorectal adenocarcinoma cell line (HT-29), and human epithelial carcinoma cell line (HeLa) are used in the evaluation procedures. In vitro assays help in the determination of the dose range of drugs for the activity. The present review highlights the in vitro cancer studies of herbal nanosuspensions using different cell lines.

Keywords: Nanosuspension, Herbal, In vitro cell lines.

(C) 2020 The Authors. Published by Innovare Academic Sciences Pvt Ltd. This is an open access article under the CC BY license (http://creativecommons. org/licenses/by/4. 0/) DOI: http://dx.doi.org/10.22159/ajpcr.2020.v13i7.37764

\section{INTRODUCTION}

Herbal medicines are used all over the world due to their low toxicity and reduced side effects than synthetic drugs [1]. The greater part of the active constituents of herbal extract is ineffective to pass lipid membranes due to their high molecular size or low solubility. Nanosuspension technology is introduced as a result of many efforts made by formulation scientists and emerged as a potent candidate for the delivery of the poorly soluble drugs in a more efficient manner. Hence, herbal extract in the form of nanosuspension may be beneficial for the treatment of various diseases [2].

In vitro bioassays are important in the evaluation of these herbal nanosuspensions with possible pharmacological effects [3]. Cell-based bioassays are used to find the pharmacological activity of formulations, and for this purpose, it requires identification of a responsive cell line. A cell line can proliferate indefinitely in an appropriate fresh medium and space. These have a major role in studying physiological, pathophysiological, and differentiation process of exact cells [4]. The cell lines possess many characteristics of normal cells, so these are used in the studies to determine whether medicinal plants have defined pharmacological activities [5].

\section{TYPES OF CELL LINES}

\section{Finite cell lines}

The cell in culture divides only a limited number of times before their growth rate decreases, and finally, they will die. The cell lines with limited culture life spans are known as finite cell lines. The cells normally divide 20-100 times before destruction. The human cells divide 50-100 times.

\section{Continuous cell lines}

A few cells in culture may get different morphology and get modified. Such types of cells are capable of growing faster and resulting in an independent culture. The progeny obtained from these modified cells have an unlimited life. They are known as continuous cell lines. These are transformed, immortal, and tumorigenic.

\section{SELECTION OF CELL LINE}

Species

Species differences are important while extrapolating the data to humans.

Finite or continues cell lines

Cultures with continuous cell lines are preferred due to their high yield.

Normal or transformed cells

The transformed cells are preferred because they are immortalized and grow quickly.

\section{Availability}

It may be produced in the laboratory.

Stability

The stability of a cell line related to cloning and storage.

Growth characteristics

- Population doubling time

- Ability to grow in suspension

- Saturation density

- Cloning efficiency [6].

\section{IN VITRO CANCER CELL LINE STUDY}

In vitro evaluation of curcumin nanosuspension against HeLa cell lines

Curcumin is the active ingredient present in the plant turmeric ( Curcuma longa ) [7], and it has a wide range of pharmacological activities including anti-cancer, anticoagulant, antithrombotics, antioxidation, and antiproliferation[8]. Curcumin used to treat the regression of psoriasis, pre-malignant lesions of the bladder, also the treatment of many cancers such as the cervix, soft palate, stomach, colorectal, and skin cancers [9-13]. Curcumin can be considered as a prospective drug due to its high safety and low cost [14].

HeLa cell lines are the most commonly used human immortal cell lines [15]; originally, it was reported from a female African-American 
individual in 1952 as cervical epithelial carcinoma, consequent analysis of tumor pathology, and clinical phenotype identified the first tumor as an uncommon adenocarcinoma [16]. HeLa has a powerful adaptation to culture conditions because it was the first cell line widely cultured [17]. It is epithelial in appearance grows fast with a doubling time of $24 \mathrm{~h}$ and shows a scarcity of contact inhibition [18]. These cells can proliferate rapidly compared to other cancer cells [19]. The stable growth of HeLa enabled the development of the polio vaccine [20], and also it is used by scientists in different types of investigations such as disease research, gene mapping, effects of toxic substances in organisms, and radiation on humans [21].

The anticancer activity of curcumin nanosuspension was assessed by MTT assay (3-(4,5-dimethylthiazol-2-yl)-2,5-diphenyltetrazolium bromide) method. The HeLa cells were exposed to curcumin nanosuspension and free curcumin solution at different concentrations $(5,10,20,40,80,160 \mu \mathrm{g} / \mathrm{ml})$ for 3 days. Empty excipients as negative control were added at equivalent concentrations as that within the tested curcumin nanosuspension. The curcumin nanosuspension and free curcumin solution inhibited the growth rate of tumor cells in a dose-dependent manner. This study suggested that curcumin nanosuspension shows higher anticancer activity than free curcumin at the same concentration due to the presence of nano-sized particles [22].

In vitro evaluation of silybin nanosuspension against prostate cancer cell lines (PC-3) and human epithelial cell line (Caco-2) cell lines

Silybin is a chemical constituent isolated from milk thistle plant (Silybum marianum) and used as a therapeutic agent for a variety of diseases, including human colon cancer, liver disease, and prostate cancer. It also suppresses the cell growth and DNA synthesis, and it is chemopreventive targeting inhibit the invasive process in prostate cancer [23-25]. This herb can be used in beta-thalassemia patients due to its immunomodulatory, iron-chelating, and antioxidant properties [26,27].

PC3 cell lines are human prostatic adenocarcinoma cell line that is used in prostatic adenocarcinoma research and drug development. These were isolated from bone metastasis and grew as an adherent layer [28]. It helps to determine biochemical changes in advanced prostate cancer cells and assessing their response to chemotherapeutic agents [29]. Other PCs-3 such as DU145 and LNCaP have low metastatic potential compared to PC-3 cell lines [30]. Protein expression of PC-3 cells may be a characteristic of small cell neuroendocrine carcinoma [31]. For the generation of subcutaneous tumor xenografts in mice, these cell lines can act as a good tool. Hence, it helps to investigate the tumor environment and therapeutic drug functionality [32].

Antitumor effect of prepared silybin nanosuspension and free silybin was done against the PC-3 cell line in an in vitro model and evaluated at different concentrations $(0.2,1,2,10,20$, and $100 \mu \mathrm{g} / \mathrm{ml})$ for 12 , 24,3 , and $48 \mathrm{~h}$ by MTT reduction assay. The inhibition rate of silybin nanosuspension to PC-3 cells increased with the concentration and time. This study suggested that silybin nanosuspension shows a higher inhibition rate than free silybin at the same concentration [33].

Caco-2 cell line originates from the human colon adenocarcinoma tissue, and it forms a monolayer of polarized enterocytes through spontaneous cellular differentiation. Caco-2 cells are shown to explicit many enzymes and display all of the four different transport routes of the intestinal epithelium [34]. Furthermore, the Caco-2 monolayer is a good in vitro model of human small intestine mucosa[35].

The anticancer activity of silybin nanosuspension against the Caco-2 cell line was determined by MTT assay. It was performed to measure the cellular viability. For the study, cell lines were incubated with silybin formulations for $8 \mathrm{~h}$ and $48 \mathrm{~h}$ at a concentration range of $10-500 \mu \mathrm{g} / \mathrm{ml}^{-1}$. When the concentration of silybin was below $125 \mu \mathrm{g} / \mathrm{ml}^{-1}$, there was no significant difference between the experimental group and the control group. Hence, this study was stated that nanosuspensions were related to no cytotoxic below the concentration of $125 \mu \mathrm{g} / \mathrm{ml}^{-1}$ [36].

In vitro evaluation of oridonin nanosuspension against human myelogenous leukemia cell line (K562) and SMMC-7721 cell lines Oridonin is a natural ent-kaurane diterpenoid extracted from the various plants such as Isodon trichocarpus, Isodon japonicas, and Isodan shikokianus [37-39]. It has various pharmacological effects including anti-inflammation, anti-bacterial, and anti-tumor activity. Mainly, it used to treat human cancers, including prostate cancer, breast cancer, and lung cancer [40-42].

K562 cell lines are myelogenous leukemia cell lines that produce less clumping in culture due to the downregulation of surface adhesion molecules by the fusion gene [43]. The cells are non-adherent and round; also, it shows a proteomic resemblance to undifferentiated granulocytes [44] and erythrocytes [45]. They easily destroyed by natural killer cells [46] because they lack the major histocompatibility complex required to inhibit natural killer cell activity [47].

The in-vitro anticancer activity of oridonin nanosuspension against K562 cell was determined by MTT assay at different concentrations of oridonin nanosuspension and free oridonin solution $(5,10,20$, 30 , and $40 \mu \mathrm{mol} / \mathrm{l})$. The incubation time was $12,18,24$, and $36 \mathrm{~h}$. The anticancer activity of oridonin nanosuspension increases with the concentration and incubation time. This study suggested that the oridonin nanosuspension shows more anticancer activity than a free oridonin solution at the same concentration. Moreover, this enhanced effect due to the presence of nanoparticles [48].

The SMMC-7721 cell line was derived in 1977 from hepatocellular carcinoma patients. This cell line expresses two receptors, that is, epidermal growth factor receptor and vascular endothelial growth factor receptor. It is an useful tool in liver cancer research [49].

MTT assay was used to determine the in vitro anticancer activity of the oridonin nanosuspension compared to the free oridonin solution against the SMMC-7721 cell line. The different concentrations $(5,10,20,30$, and $40 \mu \mathrm{mol} / \mathrm{l})$ of oridonin nanosuspension and the free oridonin solution used for the cell line study. The incubation period was 12, 24, 36, and $48 \mathrm{~h}$. Both nanosuspension and free solution inhibited the growth of SMMC-7721 cells in a time-dose-dependent manner. This study suggested that at the same concentration, oridonin nanosuspension showed a higher inhibition rate against SMMC-7721 cell line than a free oridonin solution. It may be due to the presence of a high concentration of free oridonin or uptake of nanoparticles or the combination of both [50]

In vitro evaluation of gambogenic acid nanosuspension against hepatocellular carcinoma cell line (HepG2) cell line

Gamboge is a herbal medicine derived from Garcinia hanburyi tree, and it shows pharmacological activities such as detoxification, antiinflammatory, and parasiticide effects. The main active constituent present in the plant includes gambogenic acid and gamboge. Gambogenic acid has a broad-spectrum anti-tumor effect in different cancer cell lines [51,52].

HepG2 is a human liver cancer cell line isolated from the liver tissues. This immortal cell line used in drug metabolism and hepatotoxicity studies [53,54]. These cells are epithelial in morphology, and various proteins such as albumin, fibrinogen, transferrin, and plasminogen are secreted from these HepG2 cell lines [55]. At suitable culture conditions, HepG2 cell lines show robust morphological and functional differentiation [56]. These are good in vitro model system for the study of intracellular trafficking, dynamics of bile canalicular, sinusoidal membrane proteins, and lipids in human hepatocytes [57].

The anti-tumor activity of gambogenic acid nanosuspension on the HepG2 cell line was determined by MTT assay. The HepG2 cell line 
was exposed to different concentrations $(0.5,1,2,4,8$, and $16 \mu \mathrm{M})$ of gambogenic acid nanosuspension and free gambogenic acid solution for $48 \mathrm{~h}$. The cytotoxicity of the gambogenic acid solution and gambogenic acid nanosuspension depends on the dose and concentration rate. This study suggested that the gambogenic acid nanosuspension has significant cytotoxicity to HepG2 cells than a gambogenic acid solution at an equivalent dose and it may be due to uptake of nanoparticles [58].

In vitro evaluation of Genkwanin nanosuspension against 4T1, MCF-7, MDA-MB-453, A549, and human umbilical vein endothelial cell line (HUVEC) cell lines

Genkwanin is a flavonoid isolated from Genkwa flos, Rosmarius officinalis [59], and the leaves of Cistus laurifolius [60]. It is known as a representative marker for quality control of traditional Chinese prescriptions [61]. It has various pharmacological effects, including antitussive, expectorant, anti-inflammatory [62], anti-bacterial [63], anti-plasmodial [64], radical scavenging [65], chemoprotective [66], and inhibiting $17 \beta$-hydroxysteroid dehydrogenase type 1 activities [67].

4T1 is a breast cancer cell line isolated from the mammary gland tissue of the mouse. These epithelial cells are resistant to 6-thioguanine [68]. It is mainly used to study breast cancer metastasis [69], and in live tissues, it is highly aggressive [70].

The MCF-7 is a breast cancer cell line isolated from Caucasian women [71,72] and acronym of Michigan cancer foundation-7 [73]. This noninvasive cell line represents a model of early-stage disease [74].

MDA-MB-453 cell line is a human breast cancer cell line and it has an active glycerol3-phosphate shuttle [75].

A549 cells are human epithelial cell lines developed in 1972 [76]. These types of cell lines are human alveolar basal epithelial cells [77]. These cell lines used for the study of lung cancer and also used for developing a drug against lung cancer $[78,79]$. It is responsible for the diffusion of water and electrolytes across alveoli. It is widely used as a type 2 pulmonary epithelial cell model for drug metabolism [80]. It is employed in viral research and also been studied for cell line response to tuberculosis $[81,82]$.

HUVEC cell lines are derived from human umbilical vein endothelial cells in the 1970s and used as a laboratory model system for the study of the function and pathology of endothelial cells $[83,84]$.

Anticancer activity of Genkwanin nanosuspension and Genkwanin solution against 4T1, MCF-7, MDA-MB-453, A459, and HUVEC cell lines assessed using MTT assay. Various concentrations $(0.5,1,2,5,10,20$, $50,100 \mu \mathrm{g} / \mathrm{ml}$ ) of Genkwanin nanosuspension and Genkwanin solution were used for the study. The incubation time was $48 \mathrm{~h}$. Both Genkwanin nanosuspension and Genkwanin solution inhibited cell proliferation in a dose-dependent way. This study suggested that Genkwanin nanosuspension exhibited higher cytotoxicity than the Genkwanin solution against all studied cell lines [85].

\section{In vitro evaluation of puerarin nanosuspension against HT-29 cell} line

Puerarin is an isoflavone [86] isolated from the root of the Pueraria lobata [87]. It have many beneficial effects on liver disease [88,89],cardiovascular [90,91], neurological [92,93], antiplatelet aggregation [94], and hyperglycemic disorders [95]. Furthermore, it exhibits protective actions against fever, inflammation, hyperlipidemia, osteonecrosis, and oxidative damage [96].

HT-29 cell lines are a colon cancer cell line utilized in cancer research [97]. These cells are useful for somatic cell research due to their ability to differentiate and simulate real colon tissue in vitro [98]. HT-29 cells can proliferate in cell culture with a doubling time of around 4 days without using the growth factors. The doubling time is often reduced to 1 day with added fetal bovine serum [99]. The HT-
29 cells have shown induced differentiation [100], with galactosemediated differentiation, also results in the strengthening of adherens junctions [101].

The antitumor activity of puerarin nanosuspension was evaluated by MTT assay. Various concentrations $\left(1.25,2.5,12.5\right.$, and $\left.25 \mu \mathrm{g} / \mathrm{ml}^{-1}\right)$ of puerarin nanosuspension and puerarin solution incubated for 8,16 , and $24 \mathrm{~h}$. Both the puerarin nanosuspension and puerarin solution inhibited the cell proliferation of HT-29 in a concentration timedependent manner. This study suggested that compared with puerarin free solution, nanosuspension of puerarin showed a significant increase in the cell inhibition rates under the same concentrations. The inhibitory effects increased with concentration and incubation time [102].

\section{CONCLUSION}

Herbal drugs have low side effects than synthetic drugs and also if it is formulated as nanosuspensions that it increases the solubility of drugs than conventional dosage forms. For the in vitro evaluation of herbal nanosuspensions, cell lines are mostly preferred. Because it offers easy, inexpensive, and stable platforms for the study. Here, HepG2, PC-3, K562, Caco-2, SMMC-7721,4T1, MCF-7, MDA-MB-453, A549, HUVEC, HT-29, and HeLa cell lines are used in the evaluation of different herbal nanosuspensions. Each cell line is derived from various organs and sources. MTT assays are the most commonly used method in the cell line studies to estimate the number of viable cells in multi-well plates. Cell metabolic activity can be determined using this assay method. Hence, cell lines can be used as an in vitro model for evaluation of herbal nanosuspensions.

\section{AUTHORS' CONTRIBUTIONS}

The authors declare that this work was done by the authors named in this article.

\section{CONFLICTS OF INTEREST}

There are no conflicts of interest.

\section{AUTHOR'S FUNDING}

Self-funding

\section{REFERENCES}

1. Mishra SB, Pandey H, Pandey AC. Nanosuspension of Phyllanthus amarus extract for improving oral bioavailability and prevention of paracetamol induced hepatotoxicity in Sprague-Dawly rats. Adv Natl Sci Nanotechnol 2013;4:1-6.

2. Jahan N, Aslam S, Rahman UK, Fazal T, Anwar F, Saher R. Formulation and characterization of nanosuspension of herbal extract for enhanced antiradical potential. J Exp Nanosci 2015;11:72-80.

3. Duthie SJ, Melvin WT, Burke MD. Bromobenzene detoxification in the human liver-derived HepG2 cell line. Xenobiotica 1994;24:265-79.

4. Available from: https://www.sciencedirect.com/topics/medicine-anddentistry/cell-line.

5. Pareek A, Godavarthi A, Issarani R, Nagori BP. Antioxidant and hepatoprotective activity of Fagonia schweinfurthii (Hadidi) Hadidi extract in carbon tetrachloride induced hepatotoxicity in HepG2 cell line and rats. J Ethnopharmacol 2013;150:973-81.

6. Available from: http://www.biologydiscussion.com/cell/cell-lines/ cell-lines-types-nomenclature-selection-and-maintenance-withstatistics/10517.

7. Egan ME, Pearson M, Weiner SA, Rajendran V, Rubin D, Glockner J, et al. Curcumin a major constituent of turmeric, corrects cystic fibrosis defects. Science 2004;304:600-2.

8. Anand P, Kunnumakkara AB, Newman RA, Aggarwal BB. Bioavailability of curcumin: Problems and promises. Mol Pharm 2007;4:807-18.

9. Kuttan R, Sudheeran PC, Joseph CD. Turmeric and curcumin as topical agents in cancer therapy. Tumori 1987;73:29-31.

10. Cheng AL, Hsu CH, Lin JK, Hsu MM, Ho YF, Shen TS, et al. Phase I clinical trial of curcumin, a chemopreventive agent, in patients with high-risk or pre-malignant lesions. Anticancer Res 2001;21:2895-900. 
11. Sharma RA, Euden SA, Platton SL, Cooke DN, Shafayat A, Hewitt HR, et al. Phase I clinical trial of oral curcumin: Biomarkers of systemic activity and compliance. Clin Cancer Res 2004;10:6847-54.

12. Kurd SK, Smith N, Van VA, Troxel AB, Badmaev V, Seykora JT, et al. Oral curcumin in the treatment of moderate to severe psoriasis vulgaris: A prospective clinicaltrial. J Am Acad Dermatol 2008;58:625-31.

13. Singh M, Singh N. Molecular mechanism of curcumin induced cytotoxicity in human cervical carcinoma cells. Mol Cell Biochem 2009;325:107-19.

14. Aggarwal BB, Harikumar KB. Potential therapeutic effects of curcumin, the anti-inflammatory agent, against neurodegenerative, cardiovascular, pulmonary, metabolic, autoimmune and neoplastic diseases. Int J Biochem Cell Biol 2009;41:40-59.

15. Rahbari R, Sheahan T, Modes V, Collier P, Macfarlane C, Badge RM. A novel L1 retrotransposon marker for HeLa cell line identification. Biotechniques 2009;46:277-84

16. Masters JR. HeLa cells 50 years on: The good, the bad and the ugly. Nat Rev Cancer 2002;2:315-9.

17. MacLeod RA, Dirks WG, Matsuo Y, Kaufmann M, Milch H, Drexler HG. Widespread intraspecies cross-contamination of human tumor cell lines arising at source. Int J Cancer 1999;83:555-63.

18. Stephenson EM. Locomotory invasion of human cervical epithelium and avian fibroblasts by HeLa cells in vitro. J Cell Sci 1982;57:293-314.

19. Available from: https://www.nobelprize.org/prizes/medicine/2009/ press-release.

20. Available from: https://www.vansmith.me/2017/11/12/wonder-womenthe-life-death-and-life-after-death-of-henrietta-lacks-unwittingheroine-of-modern-medical-science.

21. Jongen LM. BCR/ABL mediated downregulation of genes implicated in cell adhesion and motility leads to impaired migration toward CCR7 ligands CCL19 CCL21 in primary BCR/ABL positive cells. Leukemia 2005; 19:373-80.

22. Hong J, Liu Y, Xiao Y, Yang X, Su W, Zhang M, et al. High drug payload curcumin nanosuspensions stabilized by Mpeg-dspe and SPC: In vitro and in vivo evaluation. Drug Deliv 2017;24:109-20.

23. Velebny S, Hrckova G, Konigova A. Reduction of oxidative stress and liver injury following silymarin and praziquantel treatment in mice with mesocestoides vogae (cestoda) infection. Parasitol Int 2010;59:524-31.

24. Hogan FS, Krishnegowda NK, Mikhailova M, Kahlenberg MS. Flavonoid silibinin inhibits proliferation and promotes cell cycle arrest of human colon cancer. J Surg Res 2007;143:58-65.

25. Bhatia NZ, Woif MD, Agarwal R. Inhibition of human carcinoma cell growth and DNA synthesis by silibinin an active constituent of milk thistle; comparison with silymarin. Cancer Lett 1999;147:77-84.

26. Esfahani MA, Reisi N, Mirmoghtadaei M. Evaluating the safety and efficacy of silymarin in $\beta$-thalassemia patients: A review. Hemoglobin 2015;39:75-80.

27. Balouchi S, Gharagozloo M, Esmaeil N, Mirmoghtadaei M, Moayedi B. Serum levels of TGF $\beta$, IL-10, IL-17, and IL-23 cytokines in $\beta$-thalassemia major patients: The impact of silymarin therapy. Immunopharmacol Immunotoxicol 2014;36:271-4.

28. Available from: https://www.assets.thermofisher.com/TFSAssets/BID/ Handbooks/cancer-cell-culture-basics-handbook.pdf.

29. Timm C, Gupta A, Yin J. Robust kinetics of an RNA virus: Transcription rates are set by genome levels. Biotechnol Bioeng 2015;112:1655-62.

30. Pulukuri SM, Gondi CS, Lakka SS, Jutla A, Estes N, Gujrati M, et al. RNA interference-directed knockdown of urokinase plasminogen activator and urokinase plasminogen activator receptor inhibits prostate cancer cell invasion, survival, and tumorigenicity in vivo. J Biol Chem 2005;280:36529-40

31. Tai S, Sun Y, Squires JM, Zhang H, Oh WK, Liang CZ, et al. PC3 is a cell line characteristic of prostatic small cell carcinoma. Prostate 2011;71:1668-79.

32. Kaighn ME, Narayan KS, Ohnuki Y, Lechner JF, Jones LW. Establishment and characterization of a human prostatic carcinoma cell line(PC-3). Invest Oncol 1979;17:16-23.

33. Zheng D, Wang Y, Zhang D, Liu Z, Duan C, Jia L, et al. In vitro antitumor activity of silybin nanosuspension in PC-3 cells. Cancer Lett 2011;307:158-64

34. Beck RC, Pohlmann AR, Hoffmeister C, Gallas MR, Collnot E, Schaefer UF. Dexamethasone-loaded nanoparticle coated microparticles: Correlation between in vitro drug release and drug transport across Caco-2 cell monolayers. Eur J Pharm Biopharm 2007;67:18-30.

35. Available from: https://www.readycell.com/cacoready.

36. Wang Y, Zhang D, Liu Z, Liu G, Duan C, Jia L, et al. In vitro and in vivo evaluation of silybin nanosuspensions for oral and intravenous delivery.
Nanotechnology 2010;21:1-12.

37. Chen S, Gao J, Halicka HD, Huang X, Traganos F, Darzynkiewicz Z. The cytostatic and cytotoxic effects of oridonin (rubescenin), a diterpenoid from Rabdosia rubescens, on tumor cells of different lineage. Int J Oncol 2005;26:579-88.

38. Zhang JX, Han QB, Zhao AH, Sun HD. Diterpenoids from Isodon japonica. Fitoterapia 2003;74:435-8

39. Osawa K, Yasuda H, Maruyama T, Morita H, Takeya K, Itokawa H. Antibacterial trichorabdal diterpenes from Rabdosia trichocarpa. Phytochemistry1994;36:1287-91

40. Gao L, Zhang DR, Chen MH, Duan CX, Dai WT, Jia LJ, et al. Studies on pharmacokinetics and tissue distribution of oridonin nanosuspension. Int J Pharm 2008;355:321-7.

41. Ikezoe, T, Chen SS, Tong XJ, Heber D, Taguchi H, Koeffler HP. Oridonin induces growth inhibition and apoptosis of a variety of human cancer cell. Int J Oncol 2003;23:1187-93.

42. Ikezoe T, Chen SS, Tong XJ, Heber D, Taguchi H, Koeffler HP. Pancreatic cancer in vitro toxicity mediated by Chinese herbs SPES and PC-SPES: Implications for monotherapy and combination treatment. Cancer Lett 2003;189:59-68.

43. Lozzio BB, Lozzio CB, Bamberger EG, Feliu AS. A multipotential leukemia cell line (K562) of human origin. Proc Soc Exp Biol Med 1981;166:546-50.

44. Klein E, Ben-Bassat H, Neumann H, Ralph P, Zeuthen J, Polliack A, et al. Properties of the K562 cell line, derived from a patient with chronic myeloid leukemia. Int J Cancer 1976;18:421-31.

45. Andersson LC, Nilsson K, Gahmberg CG. K562-a human erythroleukemic cell line. Int J Cancer 1979;23:143-7.

46. Lozzio BB, Lozzio CB. Properties and usefulness of the original k-562 human myelogenous leukemia cell line. Leuk Res 1979;3:363-70.

47. Available from: https:/www.elsevier.com/books/the-leukemialymphoma-cell-line-factsbook/drexler/978-0-12-221970-2.

48. Lou H, Zhang X, Gao L, Feng F, Wang J, Wei X, et al. In vitro and in vivo antitumor activity of oridonin nanosuspension. Int $\mathrm{J}$ Pharm 2009;379:181-6

49. Available from: http://www.altogenlabs.com/xenograft-models/livercancer-xenograft/smmc-7721-xenograft -model.

50. Loua H, Gaob L, Weia X, Zhanga Z, Zhange D, Zhanga X. Oridonin nanosuspension enhances anti-tumor efficacy in SMMC-7721 cells and H22 tumor bearing mice. Colloids Surf B Biointerfaces 2011;87:319-25.

51. Li Q, Cheng H, Zhu G. Gambogenic acid inhibits proliferation of A549 cells through apoptosis inducing and cell cycle arresting. Biol Pharm Bull 2010;33:415-20.

52. Zhou A, Li QL, Peng DY. Determination of the content of gambogic acid and gambogenic acid in gamboge by HPLC. J Sep Sci 2008;15:53-4.

53. Gonzalez TL, Minsky WN, Espinosa ME, Aranda SR, Meseguer PJ, Perez CP. In vitro assessment of hepatoprotective agents against damage induced by acetaminophen and $\mathrm{CCl}_{4}$. BMC Complement Altern Med 2017; $17: 39$.

54. Donato MT, Tolosa L, Lechon JG. Culture and functional characterization of human hepatoma HepG2 cells. Methods Mol Biol 2014;1250:77-93.

55. Available from: http://www.hepg2.com

56. Theard D, Steiner M, Kalicharan D, Hoekstra D, Sven CD, Van IJ. Cell polarity development and protein trafficking in hepatocytes lacking E-cadherin $/ \beta$ catenin based adherens junctions. Mol Biol Cell 2007; 18:2313-21.

57. Moscato S, Ronca F, Campani D, Dantil S. Poly(vinyl alcohol)/gelatin hydrogels cultured with HepG2 cells as a 3D model of hepatocellular carcinoma: A morphological study. J Funct Biomater 2015;6:16-32.

58. Yuan H, Li X, Zhang C, Pan W, Liang Y, Chen Y, et al. Nanosuspension as delivery system for gambogenic acid: Characterization and in vitro/ in vivo evaluation. Drug Deliv 2015;2:1-8.

59. Altinier G, Sosa S, Aquino R, Mencherini T, Loggia DR, Tubaro A. Characterization of topical antiinflammatory compounds in Rosmarinus officinalis L. J Agric Food Chem 2007;55:1718-23.

60. Sadhu SK, Okuyama E, Fujimoto H. Prostaglandin inhibitory and antioxidant components of Cistus laurifolius, a Turkish medicinal plant. J Ethnopharmacol 2006;108:371-8.

61. Li YN, Yin LH, Xu LN, Peng JY. A simple and efficient protocol for large-scale preparation of three flavonoids from the flower of Daphne genkwa by combination of macroporous resin and counter-current chromatography. J Sep Sci 2010;33:2168-75

62. Gao Y, Liu F, Fang L, Cai R, Zong C, Qi Y, Genkwanin inhibits proinflammatory mediators mainly through the regulation of miR-101/ MKP-1/MAPK pathway in LPS-activated macrophages. PLoS One 2014;9:e96741. 
63. Martini ND, Katerere DR, Eloff JN. Biological activity of five antibacterial flavonoids from Combretum erythrophyllum (Combretaceae). J Ethnopharmacol 2004;93:207-12.

64. Kraft C, Jenett-Siems K, Siems K, Jakupovic J, Mavi S, Bienzle U, et al. In vitro antiplasmodial evaluation of medicinal plants from Zimbabwe. Phytother Res 2003;17:123-8.

65. Kim AR, Zou YN, Park TH, Shim KH, Kim MS, Kim ND, et al. Active components from Artemisia iwayomogi displaying ONOO(-) scavenging activity. Phytother Res 2004;18:1-7.

66. Suh N, Luyengi L, Fong HH, Kinghorn AD, Pezzuto JM. Discovery of natural product chemopreventive agents utilizing HL-60 cell differentiation as a model. Anticancer Res 1995;15:233-9.

67. Brozic P, Kocbek P, Sova M, Kristl J, Martens S, Adamski J, et al. Flavonoids and cinnamic acid derivatives as inhibitors of 17betahydroxysteroid dehydrogenase Type 1. Mol Cell Endocrinol 2009;301:229-34.

68. Pulaski BA, Ostrand RS. Mouse 4T1 breast tumor model. Curr Protoc Immunol 2001;20:unit 20.2.

69. Yang S, Zhang JJ, Huang XY. Mouse models for tumor metastasis. Methods Mol Biol 2012;928:221-8.

70. Bryan D, Thorpe JE, Disch BC, Bastian A, Hauser PJ, Farasyn T, et al. Development and characterization of a preclinical model of breast cancer lung micrometastatic to macrometastatic progression. PLoS One 2014;9:e98624.

71. Ismail MM, Soliman DH, Farrag AM, Sabour R. Synthesis, antitumor activity, pharmacophore modeling, and QSAR studies of novel pyrazoles and pyrazolo[1,5-A] pyramidines against breast adenocarcinoma MCF7 cell line. Int J Pharm Pharm Sci 2016;8:434-42.

72. Adrian VL, Oesterreich S, Davidson NE. MCF-7 Cells-changing the course of breast cancer research and care for 45 years. J Natl Cancer Inst 2015;107:djv073.

73. Soule HD, Vazquez J, Long A, Albert S, Brennan M. A human cell line from a pleural effusion derived from a breast carcinoma. J Natl Cancer Inst 1973;51:1409-16.

74. Kao J, Salari K, Bocanegra M. molecular profiling of breast cancer cell lines defines relevant tumor models and provides a resource for cancer gene discovery. PLoS One 2009; 4:e61446.

75. Hall RE, Birrell SN, Tilley WD, Sutherland RL. MDA-MB-453, an androgen-responsive human breast carcinoma cell line with high level androgen receptor expression. Eur J Cancer 1994;30A:484-90.

76. Available from: http://www.a549.com.

77. Durga M, Nathiya S, Devasena T. In vitro evaluation of cytotoxicity, oxidative stress, DNA damage and inflammation induced by diesel exhaust particles in human A549 lung cells and murine raw 264.7 macrophages. Int J Pharm Pharm Sci 2014;6:105-10.

78. Balashanmugam $\mathrm{P}$, Mosachristas K, Kowsalya E. In vitro cytotoxicity and antioxidant evaluation of biogenic synthesized gold nanoparticles from marsilea quadrifolia on lung and ovarian cancer cells. Int J Appl Pharm 2018;10:153-8

79. Foster KA, Oster CG, Mayer MM, Avery ML, Audus KL. Characterization of the A549 cell line as a Type II pulmonary epithelial cell model for drug metabolism. Exp Cell Res 1998;243:359-66.

80. Available from: https:/www.abcam.com/a549-whole-cell-lysateab7910.html.

81. Thomas LH, Friedland JS, Sharland M, Becker S. Respiratory syncytial virus-induced RANTES production from human bronchial epithelial cells is dependent on nuclear factor- $\mathrm{\kappa B}$ nuclear binding and is inhibited by adenovirus-mediated expression of inhibitor of $\kappa B \alpha$. J Immunol 1998;161:1007-16.

82. Lin Y, Zhang M, Barnes PF. Chemokine production by a human alveolar epithelial cell line in response to Mycobacterium tuberculosis. Infect Immun 1998;66:1121-6.
83. Park HJ, Zhang Y, Georgescu SP, Johnson KL, Kong D, Galper JB. Human umbilical vein endothelial cells and human dermal microvascular endothelial cells offer new insights into the relationship between lipid metabolism and angiogenesis. Stem Cell Rev 2006;2:93-102.

84. Jimenez N, Krouwer V, Post J. A new, rapid and reproducible method to obtain high quality endothelium in vitro. Cytotechnology 2012;65:1-14.

85. Li Y, Hong J, Li H, Qi X, Guo Y, Han M. Genkwanin nanosuspensions: A novel and potential antitumor drug in breast carcinoma therapy. Drug Deliv 2017;24:1491-500.

86. Overstreet DH, Kralic JE, Morrow AL, Ma ZZ, Zhang YW, Lee DY. NPI-031G (puerarin) reduces anxiogenic effects of alcohol withdrawal or benzodiazepine inverse or 5-HT2C agonists. Pharmacol Biochem Behav 2003;75:619-25

87. Chen R, Xue J, Xie M. Puerarin prevents isoprenalineinduced myocardial fibrosis in mice by reduction of myocardial TGF- $\beta 1$ expression. J Nutr Biochem 2012;23:1080-5

88. Liu XJ, Zhao J, Gu XY. The effects of genistein and puerarin on the activation of nuclear factor-kappaB and the production of tumor necrosis factor-alpha in asthma patients. Pharmazie 2010;65:127-31.

89. Xiao C, Li J, Dong X, He X, Niu X, Liu C, et al. Anti-oxidative and TNF-alpha suppressive activities of puerarin derivative (4AC) in RAW264.7 cells and collagen-induced arthritic rats. Eur J Pharmacol 2011;666:242-50.

90. Wu L, Qiao H, Li Y, Li L. Cardioprotective effects of the combined use of puerarin and danshensu on acute ischemic myocardial injury in rats. Phytother Res 2011;21:751-6.

91. Zhang SY, Chen G, Wei PF, Huang XS, Dai Y, Shen YJ, et al. The effect of puerarin on serum nitric oxide concentration and myocardial eNOS expression in rats with myocardial infarction. J Asian Natl Prod Res 2008;10:373-81.

92. Gu L, Yang Y, Sun Y, Zheng X. Puerarin inhibits acid-sensing ion channels and protects against neuron death induced by acidosis. Planta Med 2010;76:583-8.

93. Zhu J, Wang X, Shang Y, Xie X, Zhang F, Chen J, et al. Puerarin reduces endothelial progenitor cells senescence through augmentation of telomerase activity. Vascul Pharmacol 2008;49:106-10.

94. Hu W, Zhang Q, Yang X, Wang Y, Sun L. Puerarin inhibits adhesion molecule expression in tnf-alpha-stimulated human endothelial cells via modulation of the nuclear factor kappaB pathway. Pharmacology 2010;85:27-35

95. Meng XH, Ni C, Zhu L, Shen YL, Wang LL, Chen YY. Puerarin protects against high glucose-induced acute vascular dysfunction: Role of heme oxygenase-1 in rat thoracic aorta. Vascul Pharmacol 2009;50:110-5

96. Zhou YX, Zhang H, Peng C. Peurarin: A review of pharmacological effects. Phytother Res 2014;28:961-75.

97. Available from: https://www.link.springer.com/ chapter/10.1007\%2F978-3-319-16104-2-11.

98. Hirn M, Bivic A, Reggio H. HT-29 cells are an in vitro model for the generation of cell polarity in epithelia during embryonic differentiation. Proc Natl Acad Sci 1988;85:136-40

99. Coudray AM. Proliferation of the human colon carcinoma cell line HT29: Autocrine growth and deregulated expression of the c-myc oncogene. Cancer Res 1989;49:6566-71.

100. Cohen E. Induced differentiation in HT29, a human colon adenocarcinoma cell line. J Cell Sci 1999;112:2657-66.

101. Gout S, Marie C, Laine M, Block MR, Tavernier G, Sarlin MJ. Early enterocytic differentiation of HT-29 cells: Biochemical changes and strength increases of adherens junctions. Exp Cell Res 2004;299:498-510.

102. Wanga Y, Maa Y, Zheng Y, Song J, Yang X, Bi C. In vitro and in vivo anticancer activity of a novel puerarin nanosuspension against colon cancer, with high efficacy and low toxicity. Int J Pharm 2013;441:728-35. 